\title{
Articles
}

\section{Brønsted Acidic Ionic Liquids as Efficient Catalysts for Clean Synthesis of Carbamatoalkyl Naphthols}

\author{
Niloofar Tavakoli-Hoseini, ${ }^{*}$ Majid M. Heravi, ${ }^{\dagger}$ Fatemeh F. Bamoharram, and Abolghasem Davoodnia \\ Department of Chemistry, Faculty of Sciences, Mashhad Branch, Islamic Azad University, Mashhad, Iran \\ ${ }^{*}$ E-mail: niloofartavakoli@mshdiau.ac.ir \\ ${ }^{\dagger}$ Department of Chemistry, School of Sciences, Alzahra University, Vanak, Tehran, Iran \\ Received October 30, 2010, Accepted December 23, 2010
}

\begin{abstract}
Under mild conditions and without any additional organic solvent, synthesis of carbamatoalkyl naphthols could be carried out in the present of two halogen-free Brønsted acidic ionic liquids, 3-methyl-1-(4-sulfonic acid)butylimidazolium hydrogen sulfate and $N$-(4-sulfonic acid)butylpyridinium hydrogen sulfate. A wide range of aromatic aldehydes easily undergo condensation with $\beta$-naphthol and methyl or benzyl carbamate to afford the desired products of good purity in excellent yields. The present methodology offers several advantages such as a simple procedure with an easy work-up, short reaction times, and excellent yields. The catalysts could be recycled and reused for several times without substantial reduction in their catalytic activities.
\end{abstract}

Key Words : Brønsted-acidic ionic liquids, Carbamatoalkyl naphthols, Multicomponent reactions, Solventfree conditions

\section{Introduction}

The principles of green chemistry have been introduced to eliminate or at least to reduce the use of hazardous materials in chemical processes. One of the key areas of green chemistry is the replacement of hazardous solvents with environmentally benign ones or the elimination of solvents altogether. ${ }^{1-3}$ Ionic liquids (ILs) are salt-type compounds, which are liquids at room temperature and possessing low vapour pressure. Due to the lack of evaporation, they are considered as promising "green solvents for replacing the volatile-therefore flammable and harmful-conventional solvents. These compounds known as environmentally benign solvents or catalysts and much attention has currently been focused on the organic reactions with ILs as catalysts or solvents and many organic reactions were performed in ILs with high performance. 4-11 $^{-}$

Multi-component reactions (MCRs) have emerged as efficient and powerful tool in modern synthetic organic chemistry because the synthesis of complex organic molecules from simple and readily available substrates can be achieved in a very fast and efficient manner without the isolation of any intermediate. ${ }^{12-14}$ Therefore, the development of new MCRs and improving known MCRs are a popular area of research in current organic chemistry. A literature survey revealed that very little was known about the synthesis of carbamatoalkyl naphthols and there are only two references dealing with the synthesis of these compounds using silica supported sodium hydrogen sulfate as heterogeneous catalyst ${ }^{15}$

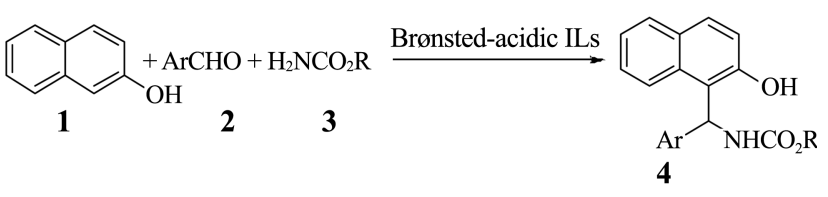

Scheme 1

and $p$-toluenesulfonic acid (TsOH) in $[\mathrm{bmim}][\mathrm{Br}]$ media. ${ }^{16}$

It is noteworthy that carbamatoalkyl naphthols can be converted to important biologically active 1-aminomethyl-2naphthol derivatives by carbamate hydrolysis. The hypotensive and bradycardiac effects of these compounds have been evaluated. ${ }^{17,18}$ Therefore, the development of new methods for their assembly is of considerable synthetic importance. ${ }^{19-22}$ With the aim to develop a more efficient synthetic process, recently, we reported the multicomponent synthesis of carbamatoalkyl naphthols using silica-supported Preyssler nano particles ${ }^{23}$ and in this paper we report a practical and inexpensive method for the synthesis of these compounds via a three-component condensation reaction between aryl aldehydes, $\beta$-naphthol, and methyl or benzyl carbamate in the presence of Brønsted acidic ILs as homogeneous catalysts under solvent-free conditions (Scheme 1).

\section{Experimental}

Some of synthesized compounds are new, and some are known. For known compounds, their physical and spectroscopic data were compared with those of authentic samples 
and found to be identical. Melting points were recorded on an electrothermal type 9100 melting point apparatus. The IR spectra were obtained using a 4300 Shimadzu spectrophotometer as $\mathrm{KBr}$ disks. The ${ }^{1} \mathrm{H}$ NMR $(500 \mathrm{MHz})$ and ${ }^{13} \mathrm{C}$ NMR $(125 \mathrm{MHz})$ spectra were recorded with a Bruker DRX500 spectrometer. Mass spectra were also obtained using a FINNIGAN-MAT 8430 mass spectrometer operating at an ionization potential of $70 \mathrm{eV}$.

Preparation of $\left[\left(\mathrm{CH}_{2}\right)_{4} \mathrm{SO}_{3} \mathrm{HMIM}\right]\left[\mathrm{HSO}_{4}\right]\left(\mathrm{IL}_{1}\right)$ and $\left.\left[\left(\mathrm{CH}_{2}\right)_{4} \mathrm{SO}_{3} \mathrm{HPY}\right]\left[\mathrm{HSO}_{4}\right] \mathbf{( I L}_{2}\right)$. A mixture of 1-methylimidazole or pyridine $(200 \mathrm{mmol})$ and 1,4-butane sultone (200 mmol) was charged into a $150 \mathrm{~mL}$ round-bottom flask. The mixture was stirred at $40{ }^{\circ} \mathrm{C}$ for $10 \mathrm{~h}$ until it turned into solid. The white solid zwitterion that formed was washed repeatedly with ether, filtered to remove non-ionic residues, and dried in vacuum. Then, a stoichiometric amount of concentrated sulfuric acid $(98 \%, 10.9 \mathrm{~mL})$ was added dropwise and the mixture stirred for $6 \mathrm{~h}$ at $80{ }^{\circ} \mathrm{C}$. Product was washed with diethyl ether and dried in vacuo at $50{ }^{\circ} \mathrm{C}$ for $2 \mathrm{~h}$ to get the viscous clear $\mathrm{IL}_{1}$ and $\mathrm{IL}_{2}{ }^{24,25}$

General Procedure for the Preparation of Carbamatoalkyl Naphthols. To a mixture of $\beta$-naphthol ( $1 \mathrm{mmol})$, aryl aldehyde $(1 \mathrm{mmol})$ and methyl or benzyl carbamate $(1.2$ mmol), $\mathrm{IL}_{1}$ or $\mathrm{IL}_{2}(10 \mathrm{~mol} \%$ base on aryl aldehyde) was added. The mixture was heated in the oil bath at $90{ }^{\circ} \mathrm{C}$. During the procedure, the reaction was monitored by TLC. Upon completion, the reaction mixture was cooled to room temperature and cold ethanol was added. The precipitate was filtered off and recrystallized from ethanol to give pure carbamatoalkyl naphthols.

Recycling of the Catalyst. Dut to the fact that the catalyst was soluble in ethanol, it could therefore be recycled of the filtrate by evaporation of the ethanol. The separated catalyst was washed with diethyl ether, dried at $50{ }^{\circ} \mathrm{C}$ under vacuum for $1 \mathrm{~h}$ and was reused in another reaction. The catalyst could be reused at least three times without significant loss of activity.

\section{Results and Discussion}

Brønsted-acidic ILs, 3-methyl-1-(4-sulfonic acid)butylimidazolium hydrogen sulfate $\left[\left(\mathrm{CH}_{2}\right)_{4} \mathrm{SO}_{3} \mathrm{HMIM}\right]\left[\mathrm{HSO}_{4}\right]$ $\left(\mathrm{IL}_{1}\right)$ and $N$-(4-sulfonic acid)butylpyridinium hydrogen sulfate $\left[\left(\mathrm{CH}_{2}\right)_{4} \mathrm{SO}_{3} \mathrm{HPY}\right]\left[\mathrm{HSO}_{4}\right]\left(\mathrm{IL}_{2}\right)$ were prepared according to the literature procedure (Figure 1 and 2 and Experimental section). The ILs prepared with this method have enough purity to be applied as catalyst in organic reactions. ${ }^{24-26}$

Initially, the reaction of benzaldehyde, $\beta$-naphthol, and methyl carbamate in the presence of $\mathrm{IL}_{1}$ was selected as a model reaction to optimize the reaction conditions.

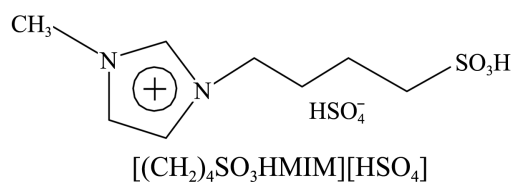

Figure 1. Brønsted-acidic $\mathrm{IL}_{1}$ structure.

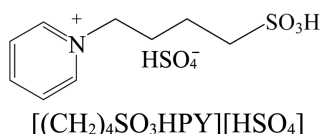

Figure 2. Brønsted-acidic $\mathrm{IL}_{2}$ structure.

The efficiency of the reaction is affected mainly by the amount of $\left[\left(\mathrm{CH}_{2}\right)_{4} \mathrm{SO}_{3} \mathrm{HMIM}\right]\left[\mathrm{HSO}_{4}\right]$ (Table 1). A trace amount of product was obtained in the absence of the catalyst even after $90 \mathrm{~min}$ at $90{ }^{\circ} \mathrm{C}$ (entry 1) indicating that the catalyst is necessary for the reaction. Increasing the amount of the catalyst increased the yield of the product $4 \mathbf{a}$. The optimal amount of the catalyst was $10 \mathrm{~mol} \%$ (entry 3 ); increasing the amount of the catalyst beyond this value did not increase the yield noticeably (entries 4 and 5).

Furthermore, the reaction was carried out in different solvents and under solvent-free conditions. As shown in Table 2, the yield of the reaction under solvent-free conditions was greater and the reaction time was generally shorter than the conventional methods.

The same model reaction in presence of $10 \mathrm{~mol} \%$ of the catalyst was carried out at different temperatures in solventfree conditions to assess the effect of temperatures on the reaction yield. It was observed that yield is a function of temperature since the yield was increased as the reaction temperature was raised (Table 2). At $90{ }^{\circ} \mathrm{C}$, the product $4 \mathbf{a}$ was obtained in high yield.

In order to evaluate the generality of this model reaction, we prepared a range of carbamatoalkyl naphthols under optimized reaction conditions in the presence of $\mathrm{IL}_{1}$ and $\mathrm{IL}_{2}$.

Table 1. Effect of the amounts of $\left[\left(\mathrm{CH}_{2}\right)_{4} \mathrm{SO}_{3} \mathrm{HMIM}\right]\left[\mathrm{HSO}_{4}\right]$ on the model reaction ${ }^{a}$

\begin{tabular}{cccc}
\hline Entry & Catalyst $(\mathrm{mol} \%)$ & Time $(\mathrm{min})$ & ${\text { Yield }(\%)^{b}}^{b}$ \\
\hline 1 & None & 90 & trace \\
2 & 5 & 5 & 74 \\
3 & 10 & 2 & 89 \\
4 & 15 & 2 & 89 \\
5 & 20 & 2 & 90 \\
\hline
\end{tabular}

$\overline{a_{1} \text { mmol benzaldehyde, } 1 \mathrm{mmol} \beta \text {-naphthol, and } 1.2 \mathrm{mmol} \text { methyl }}$ carbamate at $90{ }^{\circ} \mathrm{C} .{ }^{b}$ Isolated yields

Table 2. Synthesis of methyl [(2-hydroxynaphthalen-1-yl)(phenyl)methyl]carbamate $4 \mathrm{a}$ in the presence of $\left[\left(\mathrm{CH}_{2}\right)_{4} \mathrm{SO}_{3} \mathrm{HMIM}\right]\left[\mathrm{HSO}_{4}\right]$ $(10 \mathrm{~mol} \%)$ in different solvents

\begin{tabular}{ccccc}
\hline Entry & Solvent & $\begin{array}{c}\text { Temperature } \\
\left({ }^{\circ} \mathrm{C}\right)\end{array}$ & $\begin{array}{c}\text { Time } \\
(\mathrm{min})\end{array}$ & $\begin{array}{c}\text { Yield } \\
(\%)^{a}\end{array}$ \\
\hline 1 & $\mathrm{EtOH}$ & 78 & 15 & 68 \\
2 & $\mathrm{CH}_{3} \mathrm{CN}$ & 81 & 15 & 59 \\
3 & $\mathrm{CHCl}_{3}$ & 61 & 30 & 28 \\
4 & $\mathrm{CH}_{2} \mathrm{Cl}_{2}$ & 40 & 30 & 21 \\
5 & Solvent-free & 50 & 10 & 56 \\
6 & Solvent-free & 70 & 5 & 71 \\
7 & Solvent-free & 90 & 2 & 89 \\
8 & Solvent-free & 120 & 2 & 89 \\
\hline
\end{tabular}


Table 3. Brønsted-acidic ILs catalyzed synthesis of carbamatoalkyl naphthols 4

\begin{tabular}{|c|c|c|c|c|c|c|c|c|}
\hline \multirow{2}{*}{ Entry } & \multirow{2}{*}{ Aldehyde } & \multirow{2}{*}{ Carbamate } & \multirow{2}{*}{ Products $^{a}$} & & \multirow{2}{*}{$\begin{array}{c}\text { Time (min) } \\
\mathrm{IL}_{1} / \mathrm{IL}_{2}\end{array}$} & \multirow{2}{*}{$\begin{array}{c}\text { Yield }(\%)^{b} \\
\mathrm{IL}_{1} / \mathrm{IL}_{2}\end{array}$} & \multicolumn{2}{|c|}{$\mathrm{mp}\left({ }^{\circ} \mathrm{C}\right)$} \\
\hline & & & & & & & Found & Reported \\
\hline 1 & $\mathrm{PhCHO}$ & $\mathrm{H}_{2} \mathrm{NCO}_{2} \mathrm{Me}$ & & $4 a$ & $2 / 2$ & $89 / 87$ & $222-224$ & $217-218^{[15]}$ \\
\hline 2 & $3-\mathrm{BrC}_{6} \mathrm{H}_{4} \mathrm{CHO}$ & $\mathrm{H}_{2} \mathrm{NCO}_{2} \mathrm{Me}$ & & $4 b$ & $2 / 3$ & $90 / 88$ & 191-193 & $193-195^{[16]}$ \\
\hline 3 & $3-\mathrm{ClC}_{6} \mathrm{H}_{4} \mathrm{CHO}$ & $\mathrm{H}_{2} \mathrm{NCO}_{2} \mathrm{Me}$ & & $4 c$ & $1 / 2$ & $90 / 89$ & 201-203 & $196-198^{[15]}$ \\
\hline 4 & $4-\mathrm{ClC}_{6} \mathrm{H}_{4} \mathrm{CHO}$ & $\mathrm{H}_{2} \mathrm{NCO}_{2} \mathrm{Me}$ & & $4 d$ & $1 / 2$ & $94 / 90$ & 203-205 & $198-200^{[15]}$ \\
\hline 5 & $2,4-\mathrm{Cl}_{2} \mathrm{C}_{6} \mathrm{H}_{3} \mathrm{CHO}$ & $\mathrm{H}_{2} \mathrm{NCO}_{2} \mathrm{Me}$ & & $4 e$ & $1 / 2$ & $91 / 88$ & 194-196 & $192(\mathrm{dec})^{[15]}$ \\
\hline 6 & $2-\mathrm{MeC}_{6} \mathrm{H}_{4} \mathrm{CHO}$ & $\mathrm{H}_{2} \mathrm{NCO}_{2} \mathrm{Me}$ & & $4 f$ & $3 / 4$ & $84 / 83$ & $230-232$ & - \\
\hline 7 & $2-\mathrm{O}_{2} \mathrm{NC}_{6} \mathrm{H}_{4} \mathrm{CHO}$ & $\mathrm{H}_{2} \mathrm{NCO}_{2} \mathrm{Me}$ & & $4 g$ & $1 / 2$ & $90 / 88$ & $241-242$ & - \\
\hline 8 & $3-\mathrm{O}_{2} \mathrm{NC}_{6} \mathrm{H}_{4} \mathrm{CHO}$ & $\mathrm{H}_{2} \mathrm{NCO}_{2} \mathrm{Me}$ & & $4 h$ & $<1 / 1$ & $95 / 91$ & $253-255$ & $252(\mathrm{dec})^{[15]}$ \\
\hline 9 & $4-\mathrm{O}_{2} \mathrm{NC}_{6} \mathrm{H}_{4} \mathrm{CHO}$ & $\mathrm{H}_{2} \mathrm{NCO}_{2} \mathrm{Me}$ & & $4 \mathbf{i}$ & $<1 / 1$ & $96 / 93$ & $200-202$ & $205-207^{[15]}$ \\
\hline 10 & $\mathrm{PhCHO}$ & $\mathrm{H}_{2} \mathrm{NCO}_{2} \mathrm{Bz}$ & & $4 \mathbf{j}$ & $7 / 9$ & $85 / 84$ & $180-182$ & $179-180^{[15]}$ \\
\hline
\end{tabular}


Table 3. Continued

\begin{tabular}{|c|c|c|c|c|c|c|c|c|}
\hline \multirow{2}{*}{ Entry } & \multirow{2}{*}{ Aldehyde } & \multirow{2}{*}{ Carbamate } & \multirow{2}{*}{ Products $^{a}$} & & \multirow{2}{*}{$\begin{array}{l}\text { Time (min) } \\
\mathrm{IL}_{1} / \mathrm{IL}_{2}\end{array}$} & \multirow{2}{*}{$\begin{array}{c}\text { Yield }(\%)^{b} \\
\mathrm{IL}_{1} / \mathrm{IL}_{2}\end{array}$} & \multicolumn{2}{|c|}{$\mathrm{mp}\left({ }^{\circ} \mathrm{C}\right)$} \\
\hline & & & & & & & Found & Reported \\
\hline 11 & $3-\mathrm{BrC}_{6} \mathrm{H}_{4} \mathrm{CHO}$ & $\mathrm{H}_{2} \mathrm{NCO}_{2} \mathrm{Bz}$ & & $4 k$ & $6 / 7$ & $87 / 85$ & $183-185$ & - \\
\hline 12 & 4- $\mathrm{FC}_{6} \mathrm{H}_{4} \mathrm{CHO}$ & $\mathrm{H}_{2} \mathrm{NCO}_{2} \mathrm{Bz}$ & & 41 & $4 / 6$ & $90 / 86$ & $183-185$ & $185-186$ \\
\hline 13 & $3-\mathrm{O}_{2} \mathrm{NC}_{6} \mathrm{H}_{4} \mathrm{CHO}$ & $\mathrm{H}_{2} \mathrm{NCO}_{2} \mathrm{Bz}$ & & $4 m$ & $4 / 5$ & $91 / 89$ & 205-207 & - \\
\hline 14 & & $\mathrm{H}_{2} \mathrm{NCO}_{2} \mathrm{Me}$ & None & & $20 / 20$ & - & - & - \\
\hline 15 & & $\mathrm{H}_{2} \mathrm{NCO}_{2} \mathrm{Me}$ & None & & $20 / 20$ & - & - & - \\
\hline
\end{tabular}

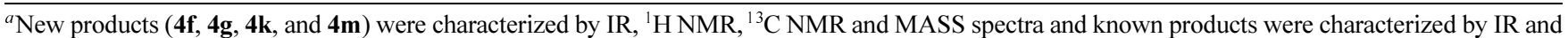
${ }^{1} \mathrm{H}$ NMR and comparison of their melting points with those of authentic samples. ${ }^{b}$ Isolated yields

The results are shown in Table 3. As shown, aromatic aldehydes with substituents carrying either electron-donating or electron-withdrawing groups reacted successfully and gave the expected products in high yields while no product could be detected using aliphatic aldehydes. It was found that the aromatic aldehydes with electron-withdrawing groups reacted faster than those with electron-donating groups as would be expected. Also, the reactions were faster in the presence of $\mathrm{IL}_{1}$ than $\mathrm{IL}_{2}$.

In comparison with other catalysts, $\mathrm{SiO}_{2}-\mathrm{NaHSO}_{4}{ }^{15}$ and $\mathrm{TsOH}$ in $[\mathrm{bmim}][\mathrm{Br}]$ media, ${ }^{16}$ the synthesis of carbamatoalkyl naphthols using Brønsted-acidic ILs, $\mathrm{IL}_{1}$ and $\mathrm{IL}_{2}$, has shorter reaction times with higher yields. On the other hand, the application of ionic liquids having halogen atoms such as $[\mathrm{bmim}][\mathrm{Br}]^{16}$ is limited due to their toxicity and environmental pollution. R. J. Bernot and co-workers reported that $[$ bmim $][\mathrm{Br}]$ is very toxic toward Daphnia magna with
LC50, $8.03 \mathrm{mg} \mathrm{L}^{-1} \cdot{ }^{27}$ Furthermore, in the synthesis of halogen based ILs, such as [bmim][Br], in general, suitable precursor, such as 1-methylimidazole, is alkylated with an appropriate alkylhalide. The quaternization reaction with alkylhalides may leave traces of halide ion in the ionic liquid. Although for many purposes this may not be a problem, halide ions can also interfere with metal catalysts, cause corrosion problems in chemical plants, and interfere with measurements of physical property of ionic liquids. ${ }^{28}$ Also, we did not find any reports about the toxicity of Brønsted-acidic ILs in the literature and there are several reports that these $\mathrm{IL}_{\mathrm{s}}$ are environment-friendly and relatively non toxic acidic catalysts. ${ }^{26,29}$ Therefore, it seems that they can be considered as green substitute for $\mathrm{H}_{2} \mathrm{SO}_{4}, \mathrm{HF}$, and $\mathrm{AlCl}_{3}$ catalysts in chemical processes. ${ }^{30}$

Reusability of the catalyst was also investigated. For this purpose, the same model reaction was again studied under

Table 4. The comparison of efficiency of $\left[\left(\mathrm{CH}_{2}\right)_{4} \mathrm{SO}_{3} \mathrm{HMIM}\right]\left[\mathrm{HSO}_{4}\right]\left(\mathrm{IL}_{1}\right)$ as catalyst in the synthesis of methyl $[(2$-hydroxynaphthalen-1yl)(phenyl)methyl]carbamate $\mathbf{4 a}$ after three times ${ }^{a}$

\begin{tabular}{lcccl}
\hline Run & $\begin{array}{c}\text { Time } \\
(\mathrm{min})\end{array}$ & $\begin{array}{c}\text { Yield } \\
(\%)^{b}\end{array}$ & $\begin{array}{c}\text { Amount of recovered } \\
\text { catalyst }(\mathrm{mg})\end{array}$ & \multicolumn{1}{l}{${ }^{1} \mathrm{H}$ NMR \& ${ }^{13} \mathrm{C} \mathrm{NMR}$ data of the catalyst } \\
\hline First & 2 & 89 & 29 & ${ }^{1} \mathrm{H} \mathrm{NMR}\left(500 \mathrm{MHz}, \mathrm{DMSO}-d_{6}, \delta \mathrm{ppm}\right): 1.51(\mathrm{~m}, 2 \mathrm{H}), 1.83(\mathrm{~m}, 2 \mathrm{H}), 2.59(\mathrm{t}, 2 \mathrm{H}, J=7.6 \mathrm{~Hz})$, \\
Second & 2 & 87 & 26 & $\begin{array}{l}3.80(\mathrm{~s}, 3 \mathrm{H}), 4.13(\mathrm{t}, 2 \mathrm{H}, J=7.0 \mathrm{~Hz}), 7.66(\mathrm{~s}, 1 \mathrm{H}), 7.72(\mathrm{~s}, 1 \mathrm{H}), 9.11(\mathrm{~s}, 1 \mathrm{H}), 9.34(\mathrm{bs}, 2 \mathrm{H}, \\
\left.\text { exchangeable with } \mathrm{D}_{2} \mathrm{O}\right) ;{ }^{13} \mathrm{C} \mathrm{NMR}\left(125 \mathrm{MHz}, \mathrm{DMSO}-d_{6}, \delta \mathrm{ppm}\right): 137.47,124.39,123.09,\end{array}$ \\
Third & 3 & 85 & 24 & $51.22,49.20,36.51,29.22,22.19$.
\end{tabular}

${ }_{1}^{a} 1 \mathrm{mmol}$ benzaldehyde, $1 \mathrm{mmol} \beta$-naphthol, $1.2 \mathrm{mmol}$ methyl carbamate, and $0.1 \mathrm{mmol}(32 \mathrm{mg})\left[\left(\mathrm{CH}_{2}\right)_{4} \mathrm{SO}_{3} \mathrm{HMIM}_{[}\left[\mathrm{HSO}_{4}\right]\left(\mathrm{IL}_{1}\right)\right.$ at $90{ }^{\circ} \mathrm{C} .{ }^{b}$ Isolated yields. ${ }^{c}$ The spectroscopic data of the catalyst before and after reactions were identical. 


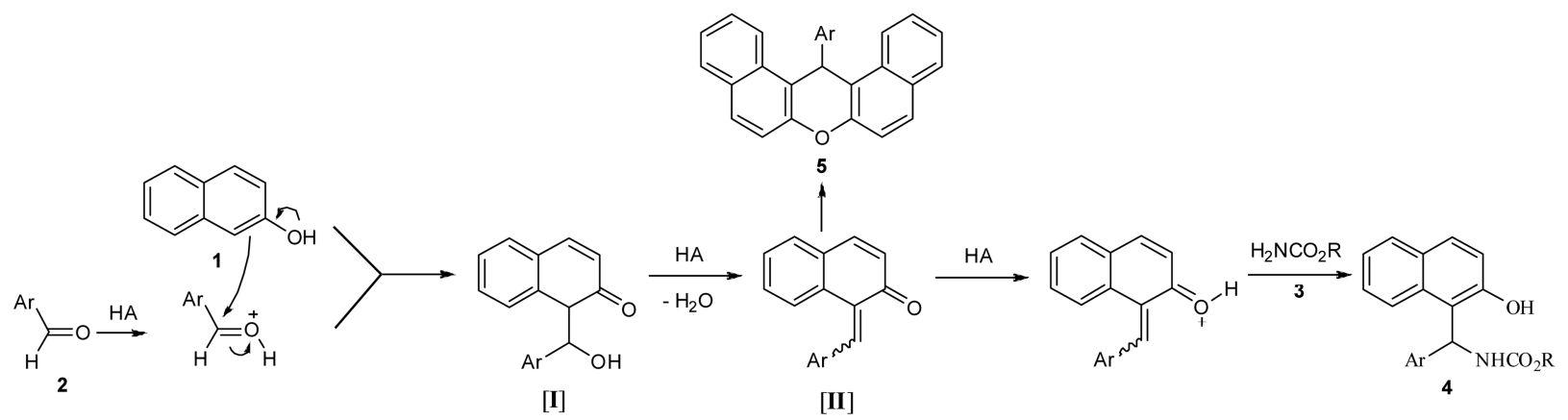

Scheme 2

optimized conditions. After the completion of the reaction, the reaction mixture was cooled to room temperature, and cold ethanol was added. The precipitated solid was filtered off and the catalyst was recovered from the filtrate by evaporation of the ethanol, dried at $50{ }^{\circ} \mathrm{C}$ under vacuum for $1 \mathrm{~h}$, and reused for a similar reaction. As shown in Table 4, the catalyst could be reused at least three times without significant loss of activity.

Although we did not investigate the reaction mechanism, based on Shaterian's suggestion, ${ }^{15}$ a plausible mechanism for the present reaction may proceed as depicted in Scheme 2. The addition of nucleophiles to the aldehydes is promoted by the protonation of the carbonyl group using a Brønsted acid, enhancing the electrophilicity of this moiety. Therefore, it is proposed that $\left(\mathrm{IL}_{1}\right)$ or $\left(\mathrm{IL}_{2}\right) \equiv \mathrm{HA}$ facilitates the formation of intermediate $[\mathbf{I}]$ such that after dehydration, intermediate [II] is produced. Nucleophilic attack of the amino group in carbamate at the $\beta$-carbon of the $\alpha, \beta$ unsaturated carbonyl group in activated intermediate [II] yields the product 4 . Under these conditions, attempts to isolate the intermediates $[\mathbf{I}]$ and $[\mathbf{I I}]$ failed after careful monitoring of reactions. On the other hand, in the absence of the carbamates, reaction of $1 \mathrm{mmol}$ aryl aldehyde with 1 mmol $\beta$-naphthol in the presence of $\mathrm{IL}_{1}$ or $\mathrm{IL}_{2}$ gave $14 \mathrm{H}$ dibenzo[a,j]xanthenes $\mathbf{5}^{31-33}$ in low yields.

\section{Conclusion}

In conclusion, we have reported a new catalytic method for the synthesis of carbamatoalkyl naphthols by one-pot condensation reaction of aromatic aldehydes, $\beta$-naphthol and methyl or benzyl carbamate using two halogen-free Brønsted-acidic ILs, [( $\left.\left.\mathrm{CH}_{2}\right)_{4} \mathrm{SO}_{3} \mathrm{HMIM}\right]\left[\mathrm{HSO}_{4}\right]\left(\mathrm{IL}_{1}\right)$ and $\left[\left(\mathrm{CH}_{2}\right)_{4} \mathrm{SO}_{3} \mathrm{HPY}\right]\left[\mathrm{HSO}_{4}\right]\left(\mathrm{IL}_{2}\right)$, as efficient, reusable, and eco-friendly homogeneous catalysts. Aromatic aldehydes with substituents carrying either electron-donating or electron-withdrawing groups reacted successfully and gave the expected products in high yields while no product could be detected using aliphatic aldehydes. The best conditions in this method is use of $10 \mathrm{~mol} \%$ of the catalyst at $90^{\circ} \mathrm{C}$ under solvent-free conditions. The catalysts can be recycled after a simple work-up, with a gradual decline of their activity being observed. High yields, short reaction times, simplicity of operation and easy work-up are just a few of the advantages of this procedure.

Spectroscopic Data for New Compounds.

Methyl [(2-hydroxynaphthalen-1-yl)(2-methylphenyl)methyl]carbamate (4f): ${ }^{1} \mathrm{H}$ NMR $\left(500 \mathrm{MHz}, \mathrm{DMSO}-d_{6}, \delta\right.$ ppm) $2.21\left(\mathrm{~s}, 3 \mathrm{H}, \mathrm{CH}_{3}\right), 3.51\left(\mathrm{~s}, 3 \mathrm{H}, \mathrm{OCH}_{3}\right), 6.79(\mathrm{~d}, 1 \mathrm{H}, J=$ $8.5 \mathrm{~Hz}, \mathrm{CH}), 7.05$ (t, $1 \mathrm{H}, J=6.5 \mathrm{~Hz}$, arom-H), 7.08-7.21 (m, $4 \mathrm{H}$, arom-H), $7.25(\mathrm{t}, 1 \mathrm{H}, J=7.5 \mathrm{~Hz}$, arom-H), $7.34(\mathrm{t}, 1 \mathrm{H}, J$ $=7.6 \mathrm{~Hz}$, arom-H), 7.67 (br, $1 \mathrm{H}, \mathrm{NH}), 7.75(\mathrm{~d}, 1 \mathrm{H}, J=8.8$ $\mathrm{Hz}$, arom-H), 7.79 (d, 1H, J=8.0 Hz, arom-H), 7.92 (d, 1H, $J=8.6 \mathrm{~Hz}$, arom-H), $9.95(\mathrm{~s}, 1 \mathrm{H}, \mathrm{OH}) ;{ }^{13} \mathrm{C}$ NMR (DMSO$d_{6}, \delta$ ppm) $154.8,153.4,146.5,136.2,133.1,131.8,131.2$, $128.8,128.3,127.4,126.6,126.2,124.8,122.3,121.7$, 117.9, 117.2, 52.4, 44.6, 23.6; IR (KBr disc) v $3427(\mathrm{NH})$, $3226(\mathrm{OH}), 1686 \mathrm{~cm}^{-1}(\mathrm{C}=\mathrm{O})$; MS, $m / z 321\left(M^{+}\right)$.

Methyl [(2-hydroxynaphthalen-1-yl)(2-nitrophenyl)methyl]carbamate (4g): ${ }^{1} \mathrm{H}$ NMR $\left(500 \mathrm{MHz}, \mathrm{DMSO}-d_{6}, \delta\right.$ ppm) $3.56\left(\mathrm{~s}, 3 \mathrm{H}, \mathrm{OCH}_{3}\right), 7.05(\mathrm{~d}, 1 \mathrm{H}, J=8.8 \mathrm{~Hz}, \mathrm{CH})$, 7.23-7.30 (m, 2H, arom-H), $7.42(\mathrm{t}, 1 \mathrm{H}, J=7.8 \mathrm{~Hz}$, arom$\mathrm{H}), 7.47(\mathrm{t}, 1 \mathrm{H}, J=7.5 \mathrm{~Hz}$, arom-H), $7.58(\mathrm{~d}, 1 \mathrm{H}, J=7.6 \mathrm{~Hz}$, arom-H), $7.63(\mathrm{t}, 1 \mathrm{H}, J=7.5 \mathrm{~Hz}$, arom-H), $7.74(\mathrm{t}, 2 \mathrm{H}, J=$ $8.6 \mathrm{~Hz}$, arom-H), 7.79 (d, 1H, $J=8.0 \mathrm{~Hz}$, arom-H), 7.87$7.95\left(\mathrm{~m}, 2 \mathrm{H}\right.$, arom-H \& NH), $9.80(\mathrm{~s}, 1 \mathrm{H}, \mathrm{OH}) ;{ }^{13} \mathrm{C} \mathrm{NMR}$ (DMSO- $d_{6}, \delta$ ppm) 157.3, 154.5, 149.5, 137.3, 133.7, 133.0, $130.8,129.9$, 129.3, 129.0, 128.6, 127.5, 124.9, 123.4, 123.3, 119.3, 116.9, 52.5, 48.7; IR (KBr disc) $3416(\mathrm{NH})$, $3271(\mathrm{OH}), 1684 \mathrm{~cm}^{-1}(\mathrm{C}=\mathrm{O}), 1522 \& 1341\left(\mathrm{NO}_{2}\right) ; \mathrm{MS}$, $m / z 352\left(M^{+}\right)$.

Benzyl [(2-hydroxynaphthalen-1-yl)(3-bromophenyl)methyl]carbamate (4k): ${ }^{1} \mathrm{H}$ NMR $\left(500 \mathrm{MHz}, \mathrm{DMSO}-d_{6}, \delta\right.$ ppm) $5.04\left(\mathrm{~d}, 1 \mathrm{H}, J=12.6 \mathrm{~Hz}, 1 \mathrm{H}\right.$ of $\left.\mathrm{CH}_{2}\right), 5.12(\mathrm{~d}, 1 \mathrm{H}, J=$ $12.6 \mathrm{~Hz}, 1 \mathrm{H}$ of $\left.\mathrm{CH}_{2}\right), 6.90(\mathrm{~d}, 1 \mathrm{H}, J=8.8 \mathrm{~Hz}, \mathrm{CH}), 7.15-$ $7.50(\mathrm{~m}, 12 \mathrm{H}$, arom-H), $7.79(\mathrm{~d}, 1 \mathrm{H}, J=8.9 \mathrm{~Hz}$, arom-H), $7.82(\mathrm{~d}, 1 \mathrm{H}, J=8.0 \mathrm{~Hz}$, arom-H), 7.85-8.00 (m, 2H, arom-H $\& \mathrm{NH}), 10.17(\mathrm{~s}, 1 \mathrm{H}, \mathrm{OH}) ;{ }^{13} \mathrm{C}$ NMR (DMSO- $\left.d_{6}, \delta \mathrm{ppm}\right)$ 157.0, 153.9, 146.2, 137.8, 132.8, 131.2, 130.5, 130.1, 129.5, $129.2,128.7,128.6,127.6,126.1,123.8,123.5,122.5$, 119.3, 119.1, 66.6, 50.8; IR (KBr disc) ৩ 3439 (NH), 3241 $(\mathrm{OH}), 1674 \mathrm{~cm}^{-1}(\mathrm{C}=\mathrm{O})$; MS, $m / z 463(M+2), 461\left(M^{+}\right)$.

Benzyl [(2-hydroxynaphthalen-1-yl)(3-nitrophenyl)methyl]carbamate (4m): ${ }^{1} \mathrm{H}$ NMR $\left(500 \mathrm{MHz}, \mathrm{DMSO}-d_{6}, \delta\right.$ ppm) $5.06\left(\mathrm{~d}, 1 \mathrm{H}, J=12.6 \mathrm{~Hz}, 1 \mathrm{H}\right.$ of $\left.\mathrm{CH}_{2}\right), 5.13(\mathrm{~d}, 1 \mathrm{H}, J=$ $12.6 \mathrm{~Hz}, 1 \mathrm{H}$ of $\left.\mathrm{CH}_{2}\right), 6.99$ (d, $\left.1 \mathrm{H}, J=8.6 \mathrm{~Hz}, \mathrm{CH}\right), 7.22$ (d, $1 \mathrm{H}, J=8.9 \mathrm{~Hz}$, arom-H), $7.30(\mathrm{t}, 2 \mathrm{H}, J=7.5 \mathrm{~Hz}$, arom-H), 7.33-7.45 (m, 5H, arom-H), 7.55 (t, $1 \mathrm{H}, J=8.0 \mathrm{~Hz}$, arom- 
H), $7.62(\mathrm{~d}, 1 \mathrm{H}, J=7.7 \mathrm{~Hz}$, arom-H), $7.81(\mathrm{~d}, 1 \mathrm{H}, J=9.0$ $\mathrm{Hz}$, arom-H), 7.83 (d, $1 \mathrm{H}, J=8.5 \mathrm{~Hz}$, arom-H), 7.94 (br, $1 \mathrm{H}$, $\mathrm{NH}), 8.07(\mathrm{~d}, 2 \mathrm{H}, J=7.9 \mathrm{~Hz}$, arom-H), 8.14 (s, 1H, arom$\mathrm{H}), 10.22(\mathrm{~s}, 1 \mathrm{H}, \mathrm{OH}) ;{ }^{13} \mathrm{C} \mathrm{NMR}$ (DMSO- $\left.d_{6}, \delta \mathrm{ppm}\right) 157.1$, $154.0,148.6,145.9,137.8,133.7,132.8,130.8,130.6$, $129.6,129.2,128.7,128.6,127.7,123.6,123.5,122.4$, 121.4, 119.3, 118.7, 66.7, 50.9; IR ( $\mathrm{KBr}$ disc) $~ 3412(\mathrm{NH})$, $3318(\mathrm{OH}), 1696 \mathrm{~cm}^{-1}(\mathrm{C}=\mathrm{O})$; MS, $m / z 428\left(M^{+}\right)$.

Acknowledgments. The authors are thankful to Islamic Azad University, Mashhad Branch for the financial support.

\section{References}

1. Anastas, P. T.; Warner, J. C. Green Chemistry: Theory and Practice; Oxford University Press: 1998; Oxford.

2. Poliakoff, M.; Fitzpatric, M. J.; Farren T. R.; Anastas, P. T. Science 2002, 297, 807.

3. Horvath, I. T.; Anastas, P. T. Chem. Rev. 2007, 107, 2167.

4. Wang, C.; Guan, W.; Xie, P.; Yun, X.; Li, H.; Hua, X.; Wang, Y. Catal. Commun. 2009, 10, 725.

5. Cole, A. C.; Jensen, J. L.; Ntai, I.; Tran, K. L. T.; Weave, K. J.; Forbes, D. C.; Davis, J. H. J. Am. Chem. Soc. 2002, 124, 5962.

6. Gui, J.; Cong, X.; Liu, D.; Zhang, X.; Hu, Z.; Sun, Z. Catal. Commun. 2004, 5, 473.

7. Gui, J.; Ban, H.; Cong, X.; Zhang, X.; Hu Z.; Sun, Z. J. Mol. Catal. A: Chemical. 2005, 225, 27.

8. Wasserscheid, P.; Sesing, M.; Korth, W. Green Chem. 2002, 4, 134.

9. Valkenberg, M. H.; DeCastro, C.; Holderich, W. F. Green Chem. 2002, 4,88

10. Qiao, K.; Yokoyama, C. Chem. Lett. 2004, 33, 472.

11. Dubreuil, J. F.; Bozureau, J. P. 2000, 41, 7351.

12. Strubing, D.; Neumann, H.; Klaus, S.; Hubner, S.; Beller, M. Tetrahedron 2005, 61, 11333.

13. Heydari, A.; Arefi, A.; Khaksar, S.; Shiroodi, R. K. J. Mol. Catal. A: Chem. 2007, 271, 142.

14. Yu, L.; Chen, B.; Huang, X. Tetrahedron Lett. 2007, 48, 925.

15. Shaterian, H. R.; Hosseinian, A.; Ghashang, M. Tetrahedron Lett. 2008, 49, 5804.
16. Dabiri, M.; Delbari, A. S.; Bazgir, A. Heterocycles 2007, 71, 543.

17. Dingermann, T.; Steinhilber, D.; Folkers, G. In Molecular Biology in Medicinal Chemistry; Wiley-VCH: 2004.

18. Shen, A. Y.; Tsai, C. T.; Chen, C. L. Eur. J. Med. Chem. 1999, 34, 877.

19. Enders, D.; Muller, S. F.; Raabe, G. Angew. Chem. Int. Ed. 1999, 38, 195.

20. Evans, D. A.; Wu, L. D.; Wiener, J. M.; Johnson, J. S.; Ripin, D. H. B.; Tedrow, J. S. J. Org. Chem. 1999, 64, 6411.

21. Kochi, T.; Tang; T. P.; Ellman, J. A. J. Am. Chem. Soc. 2002, 124, 6518-6519.

22. Murai, T.; Sano, H.; Kawai, H.; Aso, H.; Shibahara, F. J. Org. Chem. 2005, 70, 8148 .

23. Heravi, M. M.; Tavakoli-Hoseini, N.; Bamoharram, F. F. Green Chem. Lett. and Reviews in Press.

24. Wang, W.; Shao, L.; Cheng, W.; Yang, J.; He, M. Catal. Commun. 2008, $9,337$.

25. Gui, J.; Cong, X.; Liu, D.; Zhang, X.; Hu, Zh.; Sun, Zh. Catal. Commun. 2004, 5, 473

26. (a) Yang, Q.; Wei, Z.; Xing, H.; Ren, Q. Catal. Commun. 2008, 9, 1307. (b) Thi, L. T. B.; Korth, W.; Aschauer, S.; Jess, A. Green Chem. 2009, 11, 1961. (c) Davoodnia, A.; Heravi, M. M.; RezaeiDaghigh, L.; Tavakoli-Hoseini, N. Chin. J. Chem. 2010, 28, 429.

27. Bernot, R. J.; Brueseke, M. A.; Evans-White, M. A.; Lamberti, G. A. Environ. Toxicol. Chem. 2005, 24, 87.

28. McCamley, K.; Warner, N. A.; Lamoureux, M. M.; Scammells, P. J.; Singer, R. D. Green Chem. 2004, 6, 341.

29. Hajipour, A. R.; Khazdooz, L.; Ruoho, A. E. Catal. Commun. 2008, 9,89 .

30. (a) Zhao, D. B.; Wu, M.; Kou, Y.; Min, E. Z. Catal. Today 2002, 74, 157. (b) Heravi, M. M.; Saeedi, M.; Karimi, N.; Zakeri, M.; Beheshtiha, Y. S.; Davoodnia, A. Synth. Commun. 2010, 40, 523. (c) Davoodnia, A.; Heravi, M. M.; Rezaei-Daghigh, L.; TavakoliHoseini, N. Monatsh. Chem. 2009, 140, 1499. (d) Davoodnia, A.; Bakavoli, M.; Moloudi, R.; Khashi, M.; Tavakoli-Hoseini, N. Chin. Chem. Lett. 2010, $21,1$.

31. Kumar, R.; Nandi, G. C.; Verma, R. K.; Singh, M. S. Tetrahedron Lett. 2010, 51, 442.

32. Mirkhani, V.; Moghadam, M.; Tangestaninejad, S.; MohammadpoorBaltork, I.; Mahdavi, M. Synth. Commun. 2009, 39, 4328.

33. Nagarapu, L.; Baseeruddin, M.; Vijaya Kumari, N.; Kantevari, S.; Rudradas, A. P. Synth. Commun. 2007, 37, 2519. 